\title{
PEMBUANGAN SAMPAH DAN DAMPAKNYA TERHADAP MASYARAKAT DI KOTA BAU-BAU PROVINSI SULAWESI TENGGARA
}

\author{
Jumakil ${ }^{1}$ Yusuf Sabilu Lymbran Tina ${ }^{3}$ Yuslina $^{4}$ Ruslan Majid $^{5}$ Asnia Zainuddin $^{6}$ \\ ${ }^{12356}$ Fakultas Kesehatan Masyarakat Universitas Halu Oleo ${ }^{4}$ Dinas Kesehatan Kota Bau-Bau \\ jumakil@uho.ac.id'yusufsabilu@yahoo.com²lymbranizzah@gmail.com³linayus65@yahoo.co.id ${ }^{4}$ \\ ruslanmajid744@gmail.com ${ }^{5}$ asniaz76@gmail.com ${ }^{6}$
}

\begin{abstract}
Abstrak
Kota Bau-Bau menghasilkan sampah mencapai 80-100 ton per hari, setiap tahunnya mengalami peningkatan. Timbulan sampah yang terus mengalami peningkatan akan mmenimbulkan kerusakan lingkungan. Selain lingkungan dampak yang ditimbulkan sampah dapat dirasakan oleh masyarakat. Penelitian ini bertujuan untuk mengetahui cara pembuangan sampah di Kota Bau-Bau dan dampaknya terhadap masyarakat. Jenis penelitian ini adalah observational study dengan jumlah sampel 2.630 yang diambil dengan teknik propotional random sampling, responden adalah ibu rumah tangga umur 25-65 tahun. Hasil penelitian menunjukkan 53,8\% sampah dibuan ke TPS, 32,9\% dibakar 5,9\% dibuang ke sungai, 5,2\% dibuang ke halaman, 0,8\% dibuang ke lubang tanah tidak ditutup, 0,7\% dikumnpulkan kolektor pendaur ulang, 0,5\% dibuang ke lubang tanah dan ditutup, 0,2\% dibiarkan membusuk. Dampak yang ditimbulkan 44,1\% sampah berserakan, 22,1\% banyak lalat berada di , 21,9\% banyak tiku, 20,9\% banyak nyamuk, 10,7\% anjing dan kucing mencari makan, 3,8\% merasakan bau busuk yang menyengat, dan 4,1\% terjadi penyumbatan saluran air/drainase. Kesimpulan Sebagian besar masyarakat Kota Bau-Bau membuang sampah pada Tempat Pembuangan Sampah Sementara (TPS), namun masih ada yang membakar, membuang di sekitar halaman rumah, sungai, membiarkannya sampai membusuk. Dampak yang ditimbulkan dari pembuangan sampah di Kota Bau-bau adalah sampah yang berserahkan, keberadaan vektor pembawa penyakit, bau busuk yang mengganggu serta terjadi penyumbatan drainase.
\end{abstract}

Kata kunci:dampak sampah; pembuangan sampah, sampah rumah tangga

\begin{abstract}
Bau-Bau City produces 80-100 tons of waste per day, and increasing every year. Waste generation that continues to increase will cause environmental damage. In addition to the environment, the impact of waste can be felt by the community. The purpose of is aimsi to determine how to dispose of garbage in Bau-Bau City and its impact on the community. The type of research is an observational study with a total sample of 2,630 take by proportional random sampling technique, respondents are housewives aged 25-65 years. The results showed 53.8\% of the waste was dumped into the Temporary Garbage Disposal Site, 32.9\% was burned, 5.9\% was dumped into the river, $5.2 \%$ was dumped into the yard, $0.8 \%$ was dumped into an uncapped pit, $0.7 \%$ was collected by collectors recycler, $0.5 \%$ is thrown into the ground and closed, $0.2 \%$ is left to rot. The impact was $44.1 \%$ littering, $22.1 \%$ many flies were on, $21.9 \%$ many tiku, $20.9 \%$ many mosquitoes, $10.7 \%$ dogs and cats looking for food, $3.8 \%$ felt a foul odor stinging, and $4.1 \%$ occured blocked drainage. Conclusion Most people of Bau-Bau City dispose of their garbage in the Temporary Garbage Disposal Site, but there are still those who burn, throw it around the yard, river, leaving it to rot. The impacts arising from garbage disposal in Bau-bau City are surrendered rubbish, the presence of disease-carrying vectors, disturbing odors and drainage clogging.
\end{abstract}

Keywords: waste impact; garbage disposal, household waste 


\section{PENDAHULUAN}

Limbah yang dihasilkan per orang per hari di dunia rata-rata 0,74 kilogram dan sampah padat berkisarar antara 0,11 hingga 4,54 kilogram. Limbah padat dihasilkan mencapai 2,01 miliar ton setiap tahunnya di dunia, 33\% dari jumlah tersebut tidak dikelola. Jika melihat dekepan, limbah di dunia diperkirakan akan bertambah 3,40 miliar ton pada tahun 2020, dapat melebihi 2 kali lipat dari jumlah periode yang sama ${ }^{1}$.

Indonesia merupakan salah satu negera berkembang menghasilkan sampah mencapai 64 juta ton pertahunnya, bahkan tahun 2019 diperkirakan dapat mencapai 66-67 juta ton pertahun. Jenis sampah yang dihasilkan didominasi oleh sampah organik yang mencapai $60 \%$ dan sampah plastik mencapai $15 \%^{2}$.

Masyarakat Indonesi umumnya tidak peduli dengan sampah, ada sekitar 72\% masyarakat Indonesia tidak peduli dengan sampah ${ }^{3}$. Perilaku seperti ini akan berdampak pada lingkungan, bahkan manusia itu sendiri yang akan merasakan dampak buruk dari sampah yang dibuag di sembarang tempat.

Pelaksana Tugas Kepala Dinas Lingkungan Hidup Kota Bau-Bau Sumarti Lanae mengatakan bahwa Kota Bau-Bau menghasilkan sampah mencapai 80-100 ton per hari, volume sampah ini dapat meningkat diakibatkan adanya pedagang dari luar daerah masuk ke Bau-Bau ${ }^{4}$.

Timbulan sampah yang terus mengalami peningkatan akan mmenimbulkan kerusakan lingkungan. Selain lingkungan dampak yang ditimbulkan sampah dapat dirasakan oleh masyarakat. Sampah yang tidak diolah akan dibuang ke tempat pembuagan sampah bahkan ada yang akan membuang di lingkungan sekitar. Perilaku ketidak pedulian masyarakat terhadap sampah akan menimbulkan dampak negatif bagi masyarakat sendiri.

Cara pembuangan sampah yang dilakukan oleh masyarakat di Kota Bau-Bau menjadi penting dibahas karena hal ini dapat menj'adi pemicu tidak dikelolanya sampah dengan baik yang pada akhirnya dapat merusak lingkungan bahkan dapat berdampak negatif pada masyarakat seperti timbulnya berbagai jenis penyakit yang bersumber dari sampah, serta dapat menimbukkan dampak estetika yang buruk terhadap lingkungan dan masyarakat.

Penelitian ini bertujuan untuk mengetahui cara pembuangan sampah di Kota Bau-Bau dan dampaknya terhadap masyarakat

\section{METODE}

Jenis penelitian ini adalah obervasional study. Jumlah responden sebanyak 2.630 yang diambil berdasarkan jumlah rumah tempat tinggal yang ada di semua kelurahan di Kota Bau-Bau, teknik pengambilan sampel menggunakan teknik proposional random sampling agar semua kelurahan dapat terwakili menjadi sampel berdasarkan proporsi jumlah rumah tinggal. Untuk memperoleh data menggunakan kuesioner dan ibu rumah tangga umur 25-65 tahun sebagai responden.

\section{HASIL DAN PEMBAHASAN \\ Pembuangan Sampah}

Pengelolaan sampah oleh masyarakat akan sangat berpengaruh terhadap lingkungan sekitar. Pengelolaan sampah ynag baik akan mengurangi dampak negatif terhadap lingkungan dan masuarakat, sebaliknya jika pengelolaan sampah tidak bai, akan menyebabkan dampat negatif bagi lingkungan dan masyarakat. Pembuangan sampah merupakan salah satu bagian dari proses pengelolaan sampah. Masyarakat Kota Bau-Bau membuang sampah ketempat yang berbeda. Tempat pembuangan sampah di Kota Bau-Bau seperti pada tabel berikut :

Tabel1.Pembuangan Sampah oleh Masyarakat di Kota BauBau

\begin{tabular}{|c|c|c|}
\hline Tempat Pembuangan Sampah & $\mathrm{n}$ & $\%$ \\
\hline $\begin{array}{l}\text { Dikumpulkan Kolektor Pendaur } \\
\text { Ulang }\end{array}$ & 19 & 0,7 \\
\hline $\begin{array}{l}\text { Dibuang ke Tempat Penampungan } \\
\text { Sementara (TPS) }\end{array}$ & 1.416 & 53,8 \\
\hline Dibakar & 866 & 32,9 \\
\hline $\begin{array}{l}\text { Dibuang ke Lubang Tanah dan } \\
\text { Ditutup }\end{array}$ & 12 & 0,5 \\
\hline $\begin{array}{l}\text { Dibuang ke Lubang Tanah dan Tidak } \\
\text { Ditutup }\end{array}$ & 21 & 0,8 \\
\hline Dibuang ke Sungai & 155 & 5,9 \\
\hline Dibiarkan Membusuk & 4 & 0,2 \\
\hline Dibuang ke Halaman & 137 & 5,2 \\
\hline Jumlah & 2.630 & 100,0 \\
\hline
\end{tabular}
sampahnya kepada kolektor pendaur ulang di Kota Bau-Bau, artinya hanya sebagian kecil masyarakat yang memiliki perilaku mendaur ulang sampah rumah tangga. Menghadapi keadaan seperti ini dibutuhkan pendekatan kepada masyarakat secara berkesinambungan, yang mampu mendorong agar masyarakat ikut terlibat dalam pengelolaan sampai dengan cara mendaur ulang sehingga masyarakat dapat merasakan manfaatnya ${ }^{5}$. Inisiatif sampah domestik untuk dijadikan sumber energi untuk memberikan manfaat kepada masyarakat yang ikut berpartisipasi dalam proses pemisahan sampah akan menjadi pendekatan lainnya dalam rangka pengelolaan limbah padat rumah tangga yang berkelanjutan ${ }^{6}$. 
Sebagian besar responden (53,8\%) membuang sampah di Tempat Pembuangan Sampah Sementara (TPS). Cara ini banyak dipilih oleh masyarakat karena mudah dilakukan dan tidak mengotori lingkungan rumahnya. Namun ada dampak yang timbul akibat membuang sampah di TPS jika pengangkutan sampah yang dilakukan petugas pengangkut sampah baik dari swasta maupun pemerintah tidak dilakukan rutin setiap hari. Pengembangan metode pengelolaan sampah sangat dibutuhkan, termasuk sosialisasi kepada masyarakat tentang $3 \mathrm{R}$ (Reduce, Reuse and Recycle), kegiatan yang melibatkan langsung masyarakat akan lebih menyentuh dan manfaat dapat dirasakan langsung oleh masyarakat. ${ }^{7}$

Ada sebagian masyarakat Kota Bau-Bau yang membakar sampah di sekitar rumah tempat tinggal mereka. Pembakaran sampah yang dilakukan masyarakat secara terbuka dapat meningkatkan emisi gas rumah kaca. Masyarakat perlu didorong untuk merubah pola pengelolaan sampah yang selama ini dilakukan dengan pengelolaan sampah rendah emisi, misalnya dijadikan kompos. Pendirian dan penguatan bank sampah merupakan salah satu solusi untuk mengurangi timbulan sampah yang dibakar ${ }^{8}$.

Selain dibakar, masyarakat Kota Bau-Bau masih ada yang mempunyai kebiasaan membuang sampah di sembarang tempat. 5,9\% responden membuang sampah rumah tangga ke sungai, dan 5,2\% responden membuang ke halaman sekitar rumah. Bahkan masih ada $0,2 \%$ responden yang membiarkan sampahnya sampai membusuk tidak dibuang. Perilaku buruk dari sebagian kecil orang akan berdampak negeatif yang dapat dirasakan oleh banyak orang. Sampah yang dibuang ke halaman sekitar rumah akan mengotori lingkungan dan menjadi sumber penularan penyakit serta buruk secara estetika. Sampah yang sudah membusuk akan menjadi tempat perkembangbiakkan bakteri yang menjadi agent penyakit menular seperti diare, kolera dan lain-lain. Selain bakteri, sampah juga dapat menjadi tempat perkembangbiakkan lalat. Dalam tumpukan sampah volume lalat dapat berkisar antara $8-63 \%$. Spesies lalat yang berada pada area tempat pembuangan sampah, sama dengan spesies lalat lalat yang hidup di pemukiman penduduk saapai pada jarak 500 meter dari tempat penampungan sampah ${ }^{9}$

\section{Dampak Pembuangan Sampah}

Dampak yang ditimbulkan dari pembuangan sampah bermacam-macam. Di Kota Bau-Bau ada beberapa dampak yang timbul akibat dari pembuangan sampah rumah tangga seperti terlihat pada tabel berikut :
Tabel. 2 Dampak Pembuangan Sampah di Kota Bau-Bau

\begin{tabular}{|c|c|c|c|c|c|c|}
\hline \multirow{2}{*}{ Dampak } & \multicolumn{2}{|c|}{ Ya } & \multicolumn{2}{|c|}{ Tidak } & \multicolumn{2}{|c|}{ Jumlah } \\
\hline & $\mathrm{n}$ & $\%$ & $N$ & $\%$ & $n$ & $\%$ \\
\hline $\begin{array}{l}\text { Sampah } \\
\text { Berserakan }\end{array}$ & 1.160 & 44,1 & 1.470 & 55,9 & 2.630 & 100 \\
\hline $\begin{array}{l}\text { Keberadaan } \\
\text { Lalat }\end{array}$ & 580 & 22,1 & 2.050 & 77,9 & 2.630 & 100 \\
\hline $\begin{array}{l}\text { Tikus } \\
\text { Berkeliaran }\end{array}$ & 579 & 21,9 & 2.055 & 78,1 & 2.630 & 100 \\
\hline $\begin{array}{l}\text { Keberadaan } \\
\text { Nyamuk } \\
\text { Tempat }\end{array}$ & 549 & 20,9 & 2.081 & 79,1 & 2.630 & 100 \\
\hline $\begin{array}{l}\text { Mencari } \\
\text { Makan oleh } \\
\text { Kucing/Anjing }\end{array}$ & 282 & 10,7 & 2.348 & 89,3 & 2.630 & 100 \\
\hline $\begin{array}{l}\text { Bau Busuk } \\
\text { yang } \\
\text { Mengganggu } \\
\text { Menyumbat }\end{array}$ & 100 & 3.8 & 2.530 & 96,2 & 2.630 & 100 \\
\hline $\begin{array}{l}\text { Saluran } \\
\text { Drainase }\end{array}$ & 107 & 4,1 & 2.523 & 95,9 & 2.630 & 100 \\
\hline
\end{tabular}

Berdasarkan data diatas masih banyak masyarakat di kota Bau-Bau yang merasakan dampak negatif dari pembuangan sampah, $44,1 \%$ responden menilai bahwa sampah berserakan disekitar rumah maupun di luar area bak penampungan sampah sementara, 22,1\% responden melihat banyak lalat berada di tempat pembuangan sampah, $21,9 \%$ responden melihat banyak tikus berkeliaran di sekitar tumpukan sampah, 20,9\% responden melihat banyak nyamuk berada di tempat pembuangan sampah, 10,7\% responden melihat anjing dan kucing mencari makan di tempat terdapat tumpukan sampah, 3,8\% merasakan bau busuk yang menyengat dari area tempat pembuangan sampah, dan $4,1 \%$ responden melihat terjadi penyumbatan saluran air/drainase oleh sampah rumah tangga.

Sampah yang berserakan akibat tidak dikelolanya dengan baik dapat mengganggu estetika seperti pemandangan yang tidak sedap, dan dapat menjadi sumber bencana bagi masyarakat serta pencemaran udara ${ }^{10}$. Vektor penyakit sperti lalat, nyamuk dapat menjadi pembawa penyakit yang berasal dari sampah kepada manusia. Lalat sebagai vektor penyakit misalnya spesies Musca Domestica yang memiliki potensi dalam menyebarkan berbagai agent penyakit seperti protozoa, cacing, virus dan jamur. Potensi musca domestica dalam menyebarluaskan penyakit sangat tinggi karena memiliki jarak terbang yang jauh dan memiliki daya tahan terhadap kondisi lingkungan serta mempunyai kemampuan untuk memperbanyak diri. Lalat akan dengan mudah membawa agent penyakit dari tempat sampah ke rumah pemukiman ${ }^{11}$.

Binatang peliharaan juga dapat menjadi pembawa penyakit dari sampah ke pemukiman penduduk, binatang peliharaan seperti kucing dan anjing yang tidak memperloleh makanan di rumah tempatnya dipelihara akan mencari makanan di luar 
rumah. Tempat yang paling mudah untuk memperoleh makanan adalah di tempat sampah. Tepat pembuangan sampah yang mengandung banyak bibit penyakit akan menempel di mulut juga pada sebagian tubuh kucing/anjing, yang pada akhirnya akan dibawa kembali ke rumah tempat tinggalnya dan menularkan penyakit kepada orang yang tingga di rumah tersebut.

Dampak lain yang timbul akibat sampah adalah penyumbatan saluran pembuangan air/drainase. Di Kota Bau-Bau masih ada masyarakat yang melihat adanya penyumbatan drainase oleh sampah. Walaupun titik penyumbatan tidak banyak namun penyumbatan terjadi pada lokasi yang rawan banjir, jika terjadi hujan yang intensitasnya deras dapat menyebabkan bencana banjir. Tahun 2018 di Kota Bau-Bau terjadi banjir akibat hujan yang intensitasnya sangat deras sehingga terjadi luapan air sungai ${ }^{12}$. Di aderah ini setiap tahunnya merupakan daerah langganan banjir, namun ketinggiannya tidak separah tahun ini, banjir akan diperparah dengan adanya sumbatan pada drainare. Saluran drainase yang tersumbat terutama di kawasan pemukiman yang diakibatkan oleh aktifitas manusia membuang limbah pada salurann drainase sehingga terjadi penyumbatan, hal ini dapat menghambat aliran air, sehingga dapat menyebabkan banjir ${ }^{13}$.

\section{SIMPULAN DAN SARAN}

Sebagian besar masyarakat Kota Bau-Bau membuang sampah pada Tempat Pembuangan Sampah Sementara (TPS), namun masih ada yang membuang sampah di sekitar halaman rumah, sungai, bahkan ada yang membiarkannya sampai membusuk. Dampak yang ditimbulkan dari pembuangan sampah di Kota Bau-bau adalah sampah yang berserahkan, keberadaan vektor pembawa penyakit, bau busuk yang mengganggu serta terjadi penyumbatan drainase.

Pemerintah daerah melibatkan masyarakat dalam pengelolaan sampah rumah tangga, selain tidak menimbuljan dampak negatif, masyarakat juga dapat memperoleh manfaat. Pengangkutan sampah di tempat penampungan sampah sementara dilakukan rutin setiap hari agar sampah tidak berserakan dan tidak enimbulkan bau busuk.

\section{DAFTAR PUSTAKA}

1. The World Bank. 2019. Trends in Solid Waste Management [Internet]. Available from: datatopics.worldbank.org
2. Nurbaya S. 2019. Indonesia Hasilkan 67 Juta ton Sampah pada Tahun 2019. Jakarta

3. BPS. 2018. Perilaku Ketidakpedulian Lingkungan Hidup. Jakarta

4. Dwinanda R. 2019. Produksi Sampah Baubau Capai 100 Ton Per Hari. Republika [Internet]; Available from: https://www.republika.co.id

5. Setiadi A. 2015. Studi Pengelolaan Sampah Berbasis Komunitas pada Kawasan Permukiman Perkotaan di Yogyakarta. J Wil dan Lingkung;3(1).

6. Samal B, Madguni O. 2015. Interaction of Household Waste with Municipal Solid Waste : STudy of Open Dumpsites. Octa J Environ Res [Internet];3(2):129-35. Available from: http://www.sciencebeingjournal.com

7. Sari PN. 2016. Analisis Pengelolaan Sampah Padat di Kecamatan Banuhampu Kabupaten Agam. J Kesehat Masy Andalas;10(2):157-65.

8. Wahyudi J. 2109. Emisi Gas Rumah Kaca (GRK) dari Pembakaran Terbuka Sampah Rumah Tangga Menggunakan Model IPCC. J Litbang Media Inf Penelit Pengemb IPTEK BAPPEDA Kabupaten Pati [Internet];15(1):65-76. Available from: https://ejurnallitbang.patikab.go.id

9. Masyhuda, Hestiningsih R, Rahadian R. 2017. Survei Kepadatan Lalat di Tempat Pembuangan Akhir (TPA) Sampah Jatibarang Tahun 2017. J Kesehat Masy [Internet];5(4):560-9. Available from: https://ejournal3.undip.ac.id

10. Wali IN. 2011. Pengelolaan Sampah Berbasis Sosial Budaya Mengatasi Masalah Lingkungan di Bali. Bumi Lestari J Environ [Internet];11(1):167-77. Available from: https://ojs.unud.ac.id

11. Hastutiek P, Fitri LE. Potensi Musca Domestika Linn sebagai Vektor Beberapa Penyakit. 2007. J Kedokt Brawijaya [Internet];23(3):125-36. Available from: https://jkb.ub.ac.id

12. Neke D. Apr 2018. Hujan Deras, Ratusan Rumah di Bau Bau Terendam Banjir. Kompas.com [Internet]. Available from: https://regional.kompas.com

13. Novrianti. 2017. Pengaruh Drainase terhadap Lingkungan Jalan Mendawai dan sekitar Pasar Kahayan. Media IIm Tek Lingkungan, J Univ Muhammadiyah Palangkaraya [Internet];2(1):31-6. Available from: http://journal.umpalangkaraya.ac.id 